\title{
ASSOCIATION BETWEEN 72-H CUMULATIVE FLUID BALANCE AND MORTALITY IN COVID-19 PATIENTS AT RSUD DR. SOETOMOSURABAYA
}

\author{
Mochammad Ridhwan Soediono ${ }^{*}$, Bambang Pujo Semedi2**, I Gde Rurus \\ Suryawan $^{3 * * *}$, Maulydia $2 * * *$ \\ ${ }^{1}$ Faculty of Medicine, Universitas Airlangga \\ ${ }^{2}$ Departemen Anestesiologi dan Reanimasi, RSUD Dr. Soetomo \\ ${ }^{3}$ Departemen Kardiologi dan Kedokteran Vaskular, RSUD Dr. Soetomo \\ Corresponding author: Bambang Pujo Semedi, bpsemedi@gmail.com \\ * First author, ** Corresponding author, *** Co-author
}

\begin{abstract}
Cumulative fluid balance (CFB) with positive values mentioned in many studies is associated with mortality risk. In general, positive CFB was found in patients with sepsis, acute kidney injury (AKI), and heart failure. Meanwhile, COVID-19 is one of the causes of the conditions mentioned above. This study is a retrospective observational study using a cross-sectional method. Of the 97 samples obtained, 78 samples met the inclusion criteria. Obtained $69.2 \%$ male and $30.7 \%$ female. In this study, $45(57.7 \%)$ patients had positive CFB, and $33(42.3 \%)$ patients had negative CFB out of a total of 78 patients. The mortality rate was $32(41.1 \%)$ patients who died from 78 patients in August 2020 s.d. October 2020. The optimal cut-off value for the amount of CFB in 72 hours is $516 \mathrm{ml}$ (sensitivity $59.4 \%$; specificity $71.7 \%$ ). The result of the significant value of the number of CFB in 72 hours and mortality is $(\mathrm{p})=0.019$ then $\mathrm{p}<0.05$, which means there is a relationship between the number of CFBs in 72 hours and mortality in COVID-19 patients in the Ruang Isolasi Khusus (RIK) 1 RSUD Dr. Soetomo Surabaya Period August 2020-October 2020. Positive cumulative fluid balance (>516 ml) predicted to increase mortality of COVID-19 patients in Ruang Isolasi Khusus (RIK) 1 RSUD Dr. Soetomo Surabaya Period August 2020-October 2020.
\end{abstract}

Keywords: COVID-19, Cumulative Fluid Balance, Mortality

\section{INTRODUCTION}

An observational study in 198 ICUs in 24 European countries showed an association of cumulative fluid balance (CFB) in the first 72 hours with the onset of sepsis and increased mortality (1). Several studies stated that an increase in CFB was associated with the death of patients with acute kidney injury in the intensive care unit (ICU) (2). Reported in one study that 1,177 patients with sepsis had a positive cumulative fluid balance (CFB), associated with an increased risk of mortality (3). CFB is the sum of daily fluid balances within a certain period, which can be calculated by the formula [Sum of (total fluid intake-total fluid output) in the first 72 hours of care] and CFB is used as a reference for monitoring ICU patients and fluid

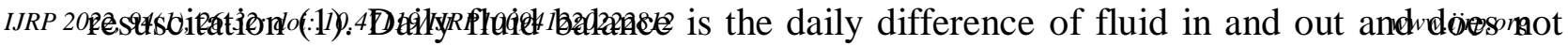


include fluid loss without cause. Patients with sepsis who receive adequate initial fluid resuscitation have a better life expectancy and shorter duration of ventilator use (4).

In December 2019, the outbreak of pneumonia caused by SARS-CoV-2 viruses began in Wuhan, the People's Republic of China; the virus has spread rapidly throughout China, with the risk of a continuing pandemic. The COVID-19 outbreak has been one of the world's health care problems in recent years. Strategies for adequate fluid resuscitation for the specific characteristics of the disease, for example, fluid overload (FO) and circulatory system failure, will help optimize the care of these patients (5). Understanding cardiovascular disorders caused by COVID-19 and knowledge of the mechanisms of disease occurrence are essential to treat patients effectively so that the mortality rate due to COVID-19 can be minimized (6). Until now, there have not been many studies discussing the direct association between COVID-19 and $\mathrm{CFB}$ and its effect on mortality; therefore, we want to know if there is an association between CFB and mortality rate in COVID-19 patients at RSUD Dr. Soetomo Surabaya within August 2020 to October 2020.

\section{METHODS OF THE STUDY}

This research uses a retrospective observational study using a cross-sectional method. The population in this study was diagnosed as COVID-19 patients with $72 \mathrm{~h}$ cumulative fluid balance monitoring in Ruang Isolasi Khusus (RIK) 1 RSUD Dr. Soetomo Surabaya within August 2020 until October 2020. Sampling was carried out by consecutive sampling, namely the technique of taking all samples that met the inclusion and exclusion criteria within a certain period. This research was conducted at the Ruang Isolasi Khusus (RIK) 1 RSUD Dr. Soetomo Surabaya as an intensive care unit for COVID-19 patients, particularly within May-August 2021. We use secondary data in the form of patient medical records. Our inclusion criteria were patients with complete cumulative fluid balance data in the first $72 \mathrm{~h}$ of treatment who had been diagnosed with confirmed COVID-19 pneumonia. We used analysis of difference and receiver operating characteristic (ROC) to obtain the significance of the CFB 72h and mortality variables and determine the optimal cut-off of CFB 72h based on Youden's index.

\section{RESULTS}

This research's data collection and processing were carried out from May to August 2021 in the Special Isolation Room of RSUD Dr. Soetomo Surabaya. The samples obtained were 97 samples from patient medical record data; 78 samples had met the inclusion criteria in 
the period range of August 2020 s.d. October 2020, the following statistical analysis tests will be carried out.

\begin{tabular}{|c|c|c|c|c|c|}
\hline \multicolumn{2}{|c|}{} & All & Survivors & $\begin{array}{c}\text { Non- } \\
\text { survivors }\end{array}$ & p \\
\hline \multirow{2}{*}{$\begin{array}{c}\text { Age, years } \\
{[\%]}\end{array}$} & $\mathbf{1 7 - 6 5}$ & $63[80,8 \%]$ & $37[80,4 \%]$ & $26[81,3 \%]$ & \multirow{2}{*}{1,000} \\
\cline { 2 - 5 } & $\geq \mathbf{6 5}$ & $15[19,2 \%]$ & $9[19,6 \%]$ & $6[18,8 \%]$ & \\
\hline \multicolumn{2}{|c|}{ Female, n $[\%]$} & $24[30,7 \%]$ & $18[39,2 \%]$ & $6[18,8 \%]$ & 0,095 \\
\hline
\end{tabular}

This study obtained the distribution of data based on age, $63(80.8 \%)$ patients aged 17 to 59 years, $15(19.2 \%)$ of the patients were aged 60 years and over, the mean value (mean) is 49 years, and the median value (median) is 51 years. There is no data for patients aged 17 years and under. Of the patients aged 17 to 59 years, 37 (80.4\%) patients survived, and patients aged 60 years and over there were $9(19.6 \%)$ patients alive. Patients who died aged 17 s.d. 59 years, $26(81.3 \%)$, and $6(18.8 \%)$ patients who died were aged 60 years and over. Through the Chisquare analysis test with power $(\alpha)=5 \%$, we got a significance value $(p)=1.00$ then $p>0.05$, which means there is no difference in mortality by age. 54 male patients $(69.2 \%)$ and $24(30.7 \%)$ female patients. The male patients who survived until the treatment period were $28(60.8 \%)$ patients and 18 (39.2\%) female patients who survived. Male patients who died were $26(81.2 \%)$ patients, and the number of female patients who died was $6(18.8 \%)$ patients. Using the Chisquare analysis test with power $(\alpha)=5 \%$, we got a significance value $(p)=0.095$ then $p>0.05$, which means there is no difference in mortality by sex. In general, this study obtained a distribution of data based on mortality, with 46 (58.9\%) patients surviving and 32 (41.1\%) patients dying out of 78 patients.

\begin{tabular}{|c|c|c|c|c|c|}
\hline \multicolumn{2}{|c|}{} & All & Survivors & Non-survivors & p \\
\hline \multirow{3}{*}{$\begin{array}{c}\text { CFB 72h } \\
(\mathbf{m l})\end{array}$} & Mean \pm SD & $\begin{array}{c}382,6 \\
\pm 209,59\end{array}$ & $\begin{array}{c}-93,44 \\
\pm 222,19\end{array}$ & $\begin{array}{c}1066,94 \\
\pm 370,57\end{array}$ & \multirow{2}{*}{0,019} \\
\cline { 2 - 5 } & Median & 240 & -109 & 657,50 & \\
\hline
\end{tabular}

In this study, we collected data on the number of patients' CFBs in the first 72 hours from entering RIK RSUD Dr. Soetomo. The results were obtained from the mean (mean) of all patients with a value of $382.6 \pm 209.59 \mathrm{ml}$ and a median value of $240 \mathrm{ml}$. The surviving patients 
received an average CFB count of $-93.44 \pm 222.19 \mathrm{ml}$ with a median value of $-109 \mathrm{ml}$. However, in patients who died, the average number of CFBs was $1066.94 \pm 370.57 \mathrm{ml}$ and a median of $657.5 \mathrm{ml}$. Then from the data described above, we carried out the Mann-Whitney analysis test and obtained the results of a significance value $(p)=0.019$ then $p<0.05$, which means a relationship between the number of CFBs and mortality.

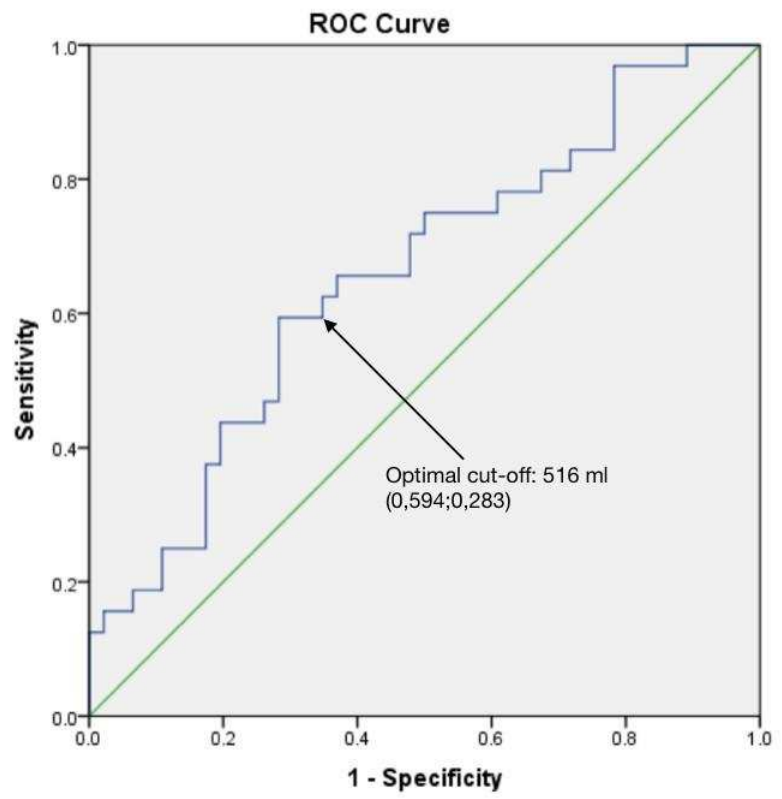

From the analysis above, we get the value of Youden's index is 0.311 , which shows the optimal cut-off value of $516 \mathrm{ml}$ (sensitivity $59.4 \%$; specificity $71.7 \%$ ) on the CFB variable within 72 hours which can be seen in the table. So it can be concluded that $59.4 \%$ of patients with CFB at $72 \mathrm{~h}>516 \mathrm{ml}$ correctly predicted were more likely to die, and patients with CFB $72 \mathrm{~h}<516 \mathrm{ml}$ correctly predicted more likely to survive. The value of the AUC is 0.657 (95\% CI $0.534-0.780$ ), which means that this analytical model is acceptable for predicting patient mortality (7).

\section{DISCUSSION}

From the total number of 78 patient data we have analyzed, the mean value is 49 years, and the median is 51 years. Different weights are mentioned in the study. The age of patients with non-COVID-19 infection cases in the ICU ranges from an average value of 66 years, with research subjects monitoring CFB patients with/without AKI or CKD (1). In patients with septic shock without COVID-19 in the ICU with CFB monitoring, it was stated that the average age of living was 62 years, and the average age of patients who died was 65 years (8). In the case of COVID-19, the patient's older age may be a factor that is also considered related to increased mortality in the presence of associated comorbidities such as cardiovascular disease, diabetes, and hypertension (9). We got data on 46 patients (58.9\%) alive, while 32 patients (41.1\%). The 
different percentages of research regarding CFB in ARDS patients without COVID-19 there were 444 living patients (74\%) and 156 patients dying (26\%) (8). As for the research of Chao, et al. stated that there were 241 patients $(81.4 \%)$ who lived and 55 patients (18.5\%) who died in the case of infected patients without COVID-19 who were treated in the ICU (10).

The results obtained from the CFB variable are 45 patients with positive CFB (57.7\%) and 33 patients with internal negative CFB (42.3\%). The significance value (p) of the number of CFBs in 72 hours and mortality was 0.019 , so $\mathrm{p}<0.05$, which means there is a relationship between the number of CFBs and mortality. We obtained a median value of $-109 \mathrm{ml}$ for the number of CFBs of living patients and $657.5 \mathrm{ml}$ of patients who died. The average number of CFB in living patients was $-93.44 \pm 222.19 \mathrm{ml}$, and in patients who died, the average was 1066.94 $\pm 370.57 \mathrm{ml}$. In the 2015 study, a different value was stated. Namely the median amount of CFB for 72 hours experienced by patients admitted to the ICU with the infection without COVID-19 was 5,100 ml, ranging from 2,700 $\mathrm{ml}$ to 3,100 $\mathrm{ml}$ (11). As for the research of Chao et al., the number of CFBs during 72 hours of treatment for infectious patients was $1710 \mathrm{ml} \pm 3011 \mathrm{ml}$, meanwhile, for survivor patients, the number of CFBs was $1431 \mathrm{ml} \pm 2807 \mathrm{ml}$, and for non-survivors, it was $2930 \mathrm{ml} \pm 3557 \mathrm{ml}$ (10). The research of Huang et al. stated that the number of CFB 72 hours of living patients was $1066.7 \mathrm{ml} \pm 348.8 \mathrm{ml}$ while patients who died were $3067.7 \mathrm{ml} \pm 446.1 \mathrm{ml}$ in the case of MODS in patients with septic shock (12).

From the analysis using the Receiver Operating Characteristic (ROC) method, we get the optimal cut-off result from the amount of CFB in 72 hours with a mortality of $516 \mathrm{ml}$ (sensitivity $59.4 \%$; specificity $71.7 \%$ ). So it can be concluded that $59.4 \%$ of patients with CFB count at $72 \mathrm{~h}>516 \mathrm{ml}$ were correctly predicted to die, and patients with CFB at $72 \mathrm{~h}<516 \mathrm{ml}$ were correctly predicted to live. Different things were reported in the study of Aragão et al. regarding positive CFB within 72 hours of ICU care patients; the optimal cut-off value was $3900 \mathrm{ml}$ (sensitivity $72.7 \%$, specificity 65.1\%) (13). de Oliveira et al. reported that CFB greater than $3000 \mathrm{ml}$ at 24 hours and 48 hours with a diagnosis of sepsis was an independent risk factor for mortality (14).

\section{CONCLUSION}

Positive cumulative fluid balance $(>516 \mathrm{ml}$ ) predicted to increase mortality of COVID-19 patients in Ruang Isolasi Khusus (RIK) 1 RSUD Dr. Soetomo Surabaya Period August 2020October 2020. 


\section{REFERENCES}

1. Neyra, J. A., Li, X., Canepa-Escaro, F., Adams-Huet, B., Toto, R. D., Yee, J., Hedayati, S. S., \& Acute Kidney Injury in Critical Illness Study Group, 2016. 'Cumulative Fluid Balance and Mortality in Septic Patients With or Without Acute Kidney Injury and Chronic Kidney Disease.' Retreived 5 November, 2020 from: https://doi.org/10.1097/CCM.0000000000001835

2. Teixeira C, Garzotto F, Piccinni P, Brienza N, Iannuzzi M, Gramaticopolo S, Forfori F, Pelaia P, Rocco M, Ronco C, Anello CB, Bove T, Carlini M, Michetti V, Cruz DN, 2013. 'Fluid balance and urine volume are independent predictors of mortality in acute kidney injury. Retreived 5 November, 2020 from: doi: 10.1186/cc12484.

3. Bouchard, J., \& Mehta, R. L., 2010. 'Fluid Balance Issues in the Critically Ill Patient.' Retreived 5 November 2020 from: doi:10.1159/000313722

4. Murphy, C. V., Schramm, G. E., Doherty, J. A., Reichley, R. M., Gajic, O., Afessa, B., Micek, S. T., Kollef, M, H., 2009. 'The Importance of Fluid Management in Acute Lung Injury Secondary to Septic Shock.' Retreived April 16, 2020 from: doi:10.1378/chest.08-2706

5. Kazory, A., Ronco, C., \& McCullough, P. A., 2020. 'SARS-CoV-2 (COVID-19) and intravascular volume management strategies in the critically ill'. Retreived 5 November, 2020 from: https://doi.org/10.1080/08998280.2020.1754700

6. Zheng, Y., Ma, Y., Zhang, J., 2020. 'COVID-19 and the cardiovascular system'. Retreived 5 November, 2020 from: https://doi.org/10.1038/s41569-020-0360-5

7. Yang, S., \& Berdine, G., 2017. 'The receiver operating characteristic (ROC) curve.' Retrieved October 27, 2021, from: https://doi.org/10.12746/swrccc.v5i19.391

8. van Mourik, N., Geerts, B. F., Binnekade, J. M. Veelo, D. P., Bos, L. D. J., Wiersinga, W. J., van der Poll, T. Cremer, O. L., Schultz, M. J., Vlaar, A. P. J., 2020. 'A Higher Fluid Balance in the Days After Septic Shock Reversal Is Associated With Increased Mortality: An Observational Cohort Study. Retrieved October 30, 2021, from doi: 10.1097/CCE.0000000000000219

9. Antos, A., Kwong M. L., Balmorez T., Villanueva A., and Murakami S., 2021. 'Unusually High Risks of COVID-19 Mortality with Age-Related Comorbidities: An Adjusted Meta-Analysis Method to Improve the Risk Assessment of Mortality Using the Comorbid Mortality Data'. Retrieved October 27 , 2021, from: https://doi.org/10.3390/idr13030065

10. Chao, W. C., Tseng, C.H., Chien, Y.C., Sheu, C.C., Tsai, M.J., 2018. 'Association of day 4 cumulative fluid balance with mortality in critically ill patients with influenza: A multicenter retrospective cohort study in Taiwan'. Retrieved October 27, 2021, from: https://doi.org/10.1371/journal.pone.0190952

11. Koonrangsesomboon, W., Khwannimit, B., 2015. 'Impact of positive fluid balance on mortality and length of stay in septic shock patients. Retrieved April 11, 2020, from https://www.ncbi.nlm.nih.gov/pmc/articles/PMC4711202/ 
12. Huang ACC, Lee TYT, Ko MC, Huang CH, Wang TY, et al., 2019. 'Fluid balance correlates with the clinical course of multiple organ dysfunction syndrome and mortality in patients with septic shock. Retrieved November 2, 2021, from: https://doi.org/10.1371/journal.pone.0225423

13. Aragão, N. L. P., Júnior, A. A. P., Feijó, C. A. R., Albuquerque, M. P., \& de Meneses, F. A., 2021. 'Positive fluid balance within the first 72 hours in the intensive care unit is associated with higher mortality in adult patients. Retrieved October 27, 2021, from: https://doi.org/10.33448/rsdv10i14.22377

14. de Oliveira, F. S., Freitas, F. G., Ferreira, E. M., de Castro, I., Bafi, A. T., de Azevedo, L. C., \& Machado, F. R., 2015. 'Positive fluid balance as a prognostic factor for mortality and acute kidney injury in severe sepsis and septic shock. Retrieved October 27, 2021, from: https://doi.org/10.1016/j.jcrc.2014.09.002 